BERNHARD GRÜMME

\title{
NIE TYLKO SZYDEŁKOWANIE I GRA W BINGO \\ STAROŚĆ JAKO WYZWANIE RELIGIJNO-PEDAGOGICZNE ${ }^{1}$
}

Ludzie starsi są odkrywani, ludziom starszym poświęca się uwagę. Weźmy choćby branżę reklamową. Jest ona dobrym barometrem trendów społecznych. Te zaś pokazują, jak dorośli i ludzie starsi są postrzegani. A wiele się w tej kwestii zmieniło. Jeszcze 10 lat temu mówiło się o ludziach starszych przede wszystkim w kontekście dolegliwości związanych $\mathrm{z}$ wiekiem. Środki przeciwbólowe, środki pielęgnacyjne do protez dentystycznych oraz ubezpieczenia emerytalne budziły największe zainteresowanie. Teraz w centrum uwagi znajdują się zupełnie inne rzeczy. Podróże, spędzanie czasu wolnego, aktywny urlop,

Artykuł jest tłumaczeniem tekstu, który ukazał się w czasopiśmie „Polonia Sacra” 19 (2015) nr 1 (38), s. 27-47, http:// dx.doi.org/10.15633/ps.728. 
operacje plastyczne. To już nie jest wizerunek krzepkiego emeryta, który pozostały mu jeszcze czas życia spędza na szydełkowaniu i grze w bingo. Osoby starsze biorą życie w swoje ręce. Kształtują je, szukają, rozwijają się, uczą się korzystać z nowych wynalazków techniki i mediów. Przed laty produkowano specjalne telefony komórkowe dla ludzi w podeszłym wieku, teraz zaś Apple organizuje kursy komputerowe właśnie dla tej grupy wiekowej. Rynek kursów fitnessu, operacji plastycznych i odnowy biologicznej dla ludzi starszych rozwija się jak mało który. Obecnie do późnego wieku dba się o swoje ciało. Mówiąc krótko, osoby starsze są odkrywane i postrzegane jako podmioty własnego życia, jako grupa docelowa reklamy, konsumpcji, stylu życia, a mniej jako przedmiot opieki i troski.

Osoby starsze są bardzo atrakcyjne dla branży reklamowej, bo przynajmniej większość z nich ma duże bezpieczeństwo finansowe i spore możliwości. Oczywiście, przez zmiany demograficzne przybywa osób starych, co w coraz większym stopniu przed poważnymi wyzwaniami stawia sprawiedliwość międzypokoleniową, opiekę oraz bezpieczeństwo materialne. Zasadniczo jednak można by powiedzieć, że starość jest fazą życia, którą aktywnie się przeżywa i kształtuje. Trzeba jednak pamiętać, że wobec rosnących wyzwań, umiejętności i zdolności konieczne są także nauka i kształcenie. 
Dorośli i starzy stają się w ten sposób także coraz ważniejsi dla psychologii uczenia się i pedagogiki. Ale jak? Jakie czynniki są tu najistotniejsze? Jaką rolę odgrywają tu katecheza oraz kształcenie religijne i wychowanie? Czy one też mają stawić czoło tym wyzwaniom? Czy w ogóle je postrzegają? Czy też w szkole i na katechezie przygotowującej do sakramentów zrobiono już wszystko, a potem nie ma już niczego istotnego, czego można by się nauczyć? Otwiera się tu rozległe pole, które omówię w czterech krokach. Po pierwsze, wyjaśnię czynniki i powody, dla których warto zajmować się ludźmi starszymi, następnie powiem o roli kształcenia dorosłych. Tę kwestię będę kontynuował w świetle kształcenia osób starszych, a na koniec naszkicuję perspektywy.

\section{1. \\ Czynniki i przyczyny}

Trzy czynniki wskazują na konieczność zajmowania się dorosłymi i starszymi w procesach kształcenia ${ }^{2}$.

2 Por. B. Schröder, Religionspädagogik, Tübingen 2012, s. 505506. 


\section{1.}

Przyspieszenie

Nowoczesność i późna nowoczesność naznaczone są postępującym przyspieszeniem ${ }^{3}$. Wszystko jest szybkie i krótkotrwałe. Liczba innowacji rośnie w ekspresowym tempie. Ten, kto dziś kupi smartfon, wie już właściwie, że jutro będzie on przestarzały. Nośników danych, które działały jeszcze przed pięcioma laty, dzisiejsze komputery nie są w stanie odczytać, ponieważ nie ma już potrzebnych do tego programów. Wiedza, wczoraj jeszcze kanoniczna, dziś już nie obowiązuje. Geniusze, tacy jak Leibniz czy Leonardo da Vinci, którzy posiedli całą wiedzę swoich czasów, są dziś niemożliwi. Trzeba się specjalizować. Te procesy niosą ze sobą konieczność ustawicznego, trwającego całe życie uczenia się. Trzeba przyswajać nowe techniki, trzeba tworzyć nowe techniki kulturowe i nowe hermeneutyki, trzeba samemu ciągle na nowo wpisywać się w owe procesy innowacji i zmian. Trzeba bowiem, również jako jednostka, dotrzymywać kro$\mathrm{ku}$ temu przyspieszeniu. Ustawiczne uczenie się jest w modzie. Uczenie się nie kończy się wraz z opuszczeniem szkoły. Trzeba uczyć się przez cały czas, również będąc człowiekiem dorosłym i starym.

3 Por. R. Hartmut, Beschleunigung. Die Veränderung der Zeitstrukturen in der Moderne, Frankfurt a. M. 2005. 
Od lat 70. mówi się o uczeniu się przez całe życie. Istnieją programy lifelong learnig organizowane przez UNESCO. W roku 2001 Komisja Europejska sformułowała tę ideę w następujący sposób: „Uczenie się przez całe życie jest wszelką, trwającą całe życie, aktywnością uczenia się z myślą o rozwoju wiedzy, kompetencji i umiejętności w perspektywie osobistej, obywatelskiej, społecznej oraz zorientowanej na zatrudnienie"' Znamienne, że nie pada tu sformułowanie „kształcenie”, natomiast mówi się o kompetencjach ważnych dla owocnego udziału w życiu społeczeństwa - zwłaszcza w interesie ekonomicznym. Widać tu ekonomizację i instrumentalizację, która pojawiła się w systemie kształcenia, szczególnie wraz z badaniami PISA i procesem bolońskim. Empatyczne pojęcie kształcenia w perspektywie filozoficznej, pedagogicznej i judeochrześcijańskiej widzi człowieka jako samostanowiącego, który decyduje o sobie w sposób wolny, autonomiczny i odpowiedzialny, przy uwzględnieniu wszystkich jego słabości i niedociągnięć, i który w ten sposób, mając krytyczną władzę sądzenia, kształtuje swoją tożsamość w kontekście społeczno-kulturowym. Według tego modelu kształcenie to nie rodzaj transferu wiedzy,

4 Cyt. za: J. Könemann, Lebenslanges Lernen: Lernen für alle - immer? Bedeutung und Wirkung eines Topos, „Diakonia” 44 (2013), s. 186. 
jak przekazanie paczki, lecz coś, czego człowiek dokonuje sam, bez funkcjonalizacji skierowanej na jakiś zewnętrzny cel, który trzeba osiągnąć. W perspektywie chrześcijańskiej należałoby to kształcenie nazwać rozwijaniem podobieństwa człowieka do Boga. Ponieważ każdy człowiek został stworzony na obraz Boży, każdy człowiek ma prawo do kształcenia. Współcześnie jednak kształcenie zostaje zredukowane do wydajności w międzynarodowym współzawodnictwie.

Choć nie jest to w tym miejscu możliwe, bardzo interesujące byłoby naświetlenie konsekwencji takiego stanu rzeczy dla kształcenia religijnego i religijnego pojmowania kształcenia ${ }^{5}$. Niemniej jednak dla nas istotne pozostaje założenie konieczności uczenia się przez całe życie. Człowiek rozumiany jest jako homo educandus, jako istota ucząca się. Uczenia się i kształcenia nie da się ograniczyć do określonej fazy życia. W pedagogice i biografistyce przyporządkowuje się je kategorii life circle i life span development. Uczenie się i kształcenie jako element całej historii życia pozbawione są granic przestrzennych, czasowych i treściowych ${ }^{6}$.

5 Por. B. Grümme, Religionsunterricht und Politik. Bestandsaufnahme - Grundsatzüberlegungen - Perspektiven für eine politische Dimension des RU, Stuttgart 2009, s. 100-149.

6 Por. J. Könemann, Lebenslanges Lernen..., dz. cyt., s. 186n. 


\section{2 .}

Psychologia rozwojowa a demografia

Jak wiadomo, psychologia rozwojowa, zwłaszcza w swoich strukturalnych modelach, stworzyła teorie genezy i rozwoju pewnych aspektów, takich jak moralność i kognicja. Wpływowa stała się teoria rozwoju Erika Eriksona, który postrzegał rozwój człowieka w określonej sekwencji faz. Każdy rozwój, począwszy od wieku niemowlęcego, poprzez wiek dziecięcy i młodzieńczy, aż po osiągniecie dorosłości kryje określone zadania rozwoju w interesie subiektywnego poczucia tożsamości. W tym sensie wiek dorosły i dojrzały mają specjalne zadania. Dorosłości przypisane jest zadanie przezwyciężenia napięcia pomiędzy „produktywnością a stagnacją", a więc kwestia, czy należy aktywnie brać w czymś udział, czy raczej wcześniej się wycofać. Stary człowiek natomiast patrząc wstecz na swoje życie musi pokonać napięcie pomiędzy integralnością a zwątpieniem: czy jestem w stanie zaakceptować swoje życie, czy potrafię je włączyć w moją tożsamość? Czy też pozostaje na końcu niepogodzenie z samym sobą??

7 Por. H.-G. Ziebertz, Wozu religiöses Lernen? Religionsunterricht als Hilfe zur Identitätsbildung, [w:] G. Hilger i in., Religionsdidaktik, München 2010, s. 144-152; A. Wittrahm, Alter als Entwicklungsaufgabe, [w:] A. Wittrahm, M. Blasberg-Kuh- 
Przy wszystkich zaletach tego modelu w badaniach naukowych krytycznie podchodzi się do ograniczenia biografii do produktywności i zarabiania. Takie patrzenie ma uzasadnienie, dopóki człowiek po zakończeniu swojej kariery zawodowej może jeszcze przeżyć konkretny, dający się oszacować czas. Tymczasem jednak o wiele lepsza opieka medyczna oraz materialna stabilizacja wpływają w znacznym stopniu na wydłużenie życia. Można założyć z dużym prawdopodobieństwem, że po zakończeniu pracy zawodowej człowiekowi pozostaje jeszcze spory odcinek życia.

W biografistyce i gerontologii mówi się w nawiązaniu do Petera Lasletta o trzeciej fazie życia, która właśnie powstaje i lokuje się pomiędzy fazą aktywności zawodowej do ok. 60. roku życia a podeszłym wiekiem i starością wraz jej z chorobami, niedomaganiem, potrzebą wsparcia i opieki ${ }^{8}$. Z trzecią fazą związane są specyficzne zadania rozwojowe, które różnie się kształtują w zależności od płci. Zacytuję tu Bernda Schrödera: „Postrzeganie i traktowanie fizycznych i psychicznych zmian (spadku wydajności fizycznej i stępienie zmysłów, zmiana inteligencji z płynnej na skrystalizowaną), przesunięcia

nke, Altern in Freiheit und Würde. Handbuch christliche Altenarbeit, München 2007, s. 85-93.

8 Por. F. Schweitzer, Postmoderner Lebenszyklus und Religion. Eine Herausforderung für Kirche und Theologie, Gütersloh 2003, s. 137-140. 
w oczekiwaniach ze strony innych (np. w odniesieniu do uczestnictwa w życiu zawodowym, kontaktu z dziećmi i wnukami, przejmowania funkcji społecznych), rozwijanie zaniedbanych dotychczas potrzeb i zainteresowań"'.

Trzecia faza życia budzi w związku z tym zainteresowanie kształceniem w ramach Kościoła, dokładnie rzecz ujmując, kształcenia dorosłych i osób starszych.

\section{3 .}

\section{Czynniki socjokulturowe}

Obecnie procesy nowoczesności zmieniły się po raz kolejny. Mówi się o późnej nowoczesności, o nowoczesności rozproszonej lub ponowoczesności ${ }^{10}$. Jakkolwiek byśmy potraktowali to niezwykle złożone pojęcie, jedno jest pewne: sposób, w jaki żyjemy, jak przeżywamy samych siebie, jak kształtujemy własną egzystencję w całej naszej biografii, bardzo się zmienił. Biografistyka mówi o postmodernistycznym cyklu życiu, nazywając w ten sposób zjawiska, które są zupełnie nowe. Coraz bardziej zanika tzw. normalna biografia. Już sam wybór miejsca pracy, przyjaciół i miejsca zamieszkania bardzo się uelastycznił.

B. Schröder, Religionspädagogik, dz. cyt., s. 506.

10 Por. R. Bergold, R. Boschki, Einführung in die religiöse Erwachsenenbildung, Darmstadt 2014, s. 20-27. 
Zniknęły stałe wzorce biograficzne. Poprzez społeczne procesy indywidualizacji biografia staje się własnym projektem egzystencjalnym, z wszelkimi szansami większej wolności i wszelkim ryzykiem poczucia rosnącego wykorzenienia i braku bezpieczeństwa. Stare wzorce nie zdają się już na nic. Obraz rodziny się chwieje ${ }^{11}$. To wszystko pokazuje bardzo jaskrawo, jakim wyzwaniem jest życie aż po sędziwy wiek. Nie chodzi o to, żeby je po prostu przeżyć, trzeba je kształtować i formować. To jednak oznacza potrzebę kształcenia się w podeszłym wieku. Starość musi być przedmiotem i aspektem kształcenia dorosłych, a tym samym także kształcenia dorosłych i osób starszych w ramach Kościoła - w każdym razie jeśli traktuje ono własne postulaty poważnie.

\section{2. \\ Kształcenie dorosłych w ramach Kościoła}

Kościelne formy kształcenia dorosłych to nie to samo co szkolna pedagogika religii czy katecheza dla dorosłych $^{12}$. Mają z nimi wiele punktów wspólnych, ale

11 Por. F. Schweitzer, Religionspädagogik, Gütersloh 2006, s. 254256.

12 Por. M. Blasberg-Kuhnke, Gerontologie und praktische Theologie. Studien zu einer Neuorientierung der Altenpastoral, Düsseldorf 1985; R. Englert, Religiöse Erwachsenenbildung. Situa- 
posiadają jak najbardziej własny profil. Z tymi dziedzinami dzielą one przede wszystkim wymienione właśnie założenia społecznokulturowe, zwłaszcza prowokacje, wychodzące w związku z ekonomizacją i funkcjonalizacją ze strony kształcenia w sensie autonomicznego sądzenia i samostanowienia.

Do tego dochodzą szczególne wyzwania, związane $\mathrm{z}$ obecnymi transformacjami na polu religijnym. Religie z jednej strony się zsekularyzowały. Nie zniknęły jednak, lecz częściowo się spluralizowały i zindywidualizowały. Stwierdza się upadek tradycji i przerwanie ciągłości wiary. Do tego dochodzi, zwłaszcza w Niemczech wschodnich, rosnąca areligijność. Wpisana w społeczno-kulturowe procesy indywidualizacji religia, która w niektórych środowiskach była przekazywana z pokolenia na pokolenie i znajdowała swoje miejsce w kulturze i życiu jako coś oczywistego, staje się przedmiotem wyboru w służbie podmiotu i określania własnej tożsamości. A przy tym duchowość zyskuje na znaczeniu, lecz jej pojęcie się zmieniło z pełnego treści odniesienia do konieczności, w odniesienie do osobowego Boga, w wykraczające poza codzienność poszerzenie i pogłębienie własnego „ja”

tion - Probleme - Handlungsorientierung, Stuttgart 1992; Konstrukte gelingenden Alterns, Hg. M. Kumlehn, A. Kubik, Stuttgart 2012; Erwachsenenbildung stellt sich religiöser Pluralität, Hg. R. Englert, S. Leimgruber, Freiburg i. Br. 2005. 
w religii niewidocznej zupełnie współcześnie, wchłoniętej przez kulturę. Futbol, sport, kapitalizm, fitness stały się takimi miejscami duchowości i religii popularnej ${ }^{13}$. Peter Berger związane $\mathrm{z}$ tym synkretyzmy umiejscowił w kontekście ,imperatywu heretyckiego" ${ }^{\prime 1}$. W ten sposób zmienia się także sama religia. Wykształcają się wielkie i małe transcendencje, które wnoszą jakieś „więcej“, jakieś ,jeszcze nie” w codzienność, nie odnosząc się jednak do żadnej bezwzględnej transcendencji ${ }^{15}$.

Kontekst jest zatem wspólny. O różnicach pomiędzy kościelnym kształceniem dorosłych, lekcjami religii oraz katechezą stanowią przede wszystkim treści, cele i podmioty. Istotne jest przede wszystkim kategorialne rozróżnienie uczynione na synodzie katolickich biskupów niemieckich w Würzburgu w 1975 roku: katechezę i nauczanie religii trzeba przy wszelkim ich wzajemnym powiązaniu wyraźnie rozróżniać co do ich założeń i celów. Katecheza służy nauczaniu,

13 Por. H. Knoblauch, Populäre Religion. Auf dem Weg in eine spirituelle Gesellschaft, Frankfurt a. M. 2009; J. Könemann, Kontexte und Bedingungen religiös-theologischer Erwachsenenbildung, „Forum Erwachsenenbildung. Beiträge und Berichte" Heft 3 (2010), s. 4-9.

14 Por. P. L. Berger, Der Zwang zur Häresie. Religion in der pluralistischen Gesellschaft, Freiburg i. Br. 2000.

15 Por. B. Grümme, Menschen bilden. Eine religionspädagogische Anthropologie, Freiburg i. Br. 2012, s. 26-60; Ch. Taylor, Ein Säkulares Zeitalter, Frankfurt a. M. 2009. 
intensyfikacji danej już wiary, co w warunkach religijnego pluralizmu może przybierać różne formy. Lekcje religii w szkołach publicznych natomiast nie mają na celu wiary, lecz osiągnięcie zdolności krytycznego rozumowania w obrębie religii. Zawiera ono oczywiście także w sposób konieczny prócz wiedzy wewnętrzną perspektywę odwołującą się do doświadczenia, bo przecież w rzeczywistości można tylko to ocenić, czego się doświadczy, do czego jest się zdolnym w języku, postępowaniu i właśnie poprzez wiedzę. Lekcja katechezy w szkole publicznej w pluralistycznym kontekście podważałaby religijną wolność uczniów i byłaby ingerowaniem w ich życie ${ }^{16}$.

Jeśli należy rozróżniać lekcje religii, katechezę i pedagogikę religii, głoszenie wiary i kształcenie religijne, to to samo należy zrobić w dziedzinie kształcenia dorosłych. To niemały problem, że obecnie w specyficznych warunkach odchodzenia od Kościoła w Niemczech również w dziedzinie kształcenia dorosłych i ludzi starszych istnieje niebezpieczeństwo zatarcia granic. Kształcenie dorosłych podporządkowywane jest wówczas katechezie, a nawet katechezie parafialnej lub duszpasterstwu parafialnemu, zamiast być krytycznie i produktywnie ukierunkowane na nią. $\mathrm{W}$ ten sposób wpisuje się ono z założenia

16 Por. B. Grümme, Religionsunterricht und Politik..., dz. cyt., s. $15-50$. 
w procesy wspólnotowe parafii, a nie przede wszystkim $\mathrm{w}$ procesy kształtowania tożsamości i autono$\mathrm{mii}^{17}$. O ile katecheza dorosłych zorientowana jest kerygmatycznie, na głoszenie wiary ${ }^{18}$, o tyle kościelne kształcenie dorosłych koncentruje się na kształceniu podmiotów, które jeszcze ostrzej niż w przypadku religijnego kształcenia dorosłych obejmuje cały obszar religijności i odbywa się horyzoncie chrześcijańskim ${ }^{19}$.

Jednym z centralnych aspektów kształcenia jest odniesienie do tego, co można by nazwać religijnością dorosłych. Ta zaś różni się od religijności i wiary młodych przede wszystkim trzema podstawowymi kategoriami: transformacji, sprawdzenia się i powołania. Religijność dorosłych jest dojrzała wówczas, gdy okazuje się zdolna do rozwoju w życiowych sytuacjach kryzysowych (transformacja); kiedy normy i wizje udanego życia w sytuacjach kryzysowych sprawdzają się jako wskazujące drogę naprzód i jeśli

17 Por. J. Könemann, Konsequenzen aus den pastoralen Entwicklungen für die Erwachsenenbildung, „Erwachsenenbildung“" 57 (2010), s. 146-150.

18 Por. K. Becker, Konzeptionen der Erwachsenenkatechese, [w:] Handbuch der Katechese, Hg. A. Kaupp u. a., Freiburg i. Br. 2011, s. 432-445.

19 Por. Ch. Mulia, Kirchliche Altenbildung: Herausforderungen - Perspektiven - Konsequenzen, Stuttgart 2011, s. 94-96; R. Bergold, R. Boschki, Einführung in die religiöse Erwachsenenbildung, dz. cyt., s. 65-73. 
można w nich doświadczyć wyzwalającej oraz pobudzającej siły obecności Boga (powołanie) ${ }^{20}$.

Poprzez to odniesienie do szczególnych uwarunkowań religijności podmiotów oraz ich autonomii z jednej strony oraz poprzez inspiracje oraz odniesione do prawdy modele orientacji w świecie, pochodzące $z$ tradycji judeochrześcijańskiej, w kontekstach kościelnych z drugiej strony podkreślone zostaje specyficzne napięcie towarzyszące kształceniu dorosłych w ramach Kościoła. Z jednej strony musi ono zachować swoją kościelną tożsamość. Kościół jako wspólnota wierzących jest zawsze także wspólnotą uczących się. Wiara potrzebuje kształcenia, podobnie jak kształcenie odnosi się do wiary. Jako część religijnej samorealizacji kształcenie dorosłych przyczynia się do dojrzałego chrześcijaństwa, które wreszcie normy krytyczne czyni skutecznymi w aspekcie kościelno-krytycznym. Z drugiej strony zaś kształcenie jako „szkoła języka wolności” musi być skuteczne w sensie społeczno-politycznym i kulturowym ${ }^{21}$. I właśnie dla publicznej pedagogiki religii ta dialektyka wewnętrznej i zewnętrznej perspektywy kształcenia dorosłych jest podstawowa ${ }^{22}$.

20 Por. W. Fürst, A. Wittram, Gestalten erwachsener Religiosität, NHbrpGb 2002, s. 204-209; tu: 207.

21 Por. B. Grümme, Religionsunterricht und Politik, dz. cyt., s. $120-155$.

22 Por. B. Grümme, Bildungsgerechtigkeit. Eine religionspädagogische Herausforderung, Stuttgart 2014. 
Kształcenie dorosłych organizowane przez Kościół charakteryzuje się wyraźnym ukierunkowaniem na uczestników i podmiot. W przeciwieństwie do lekcji religii opiera się na zasadzie dobrowolności i bazuje na międzypokoleniowości, jeśli uczą się różne grupy wiekowe. Oferta jest dopasowana do sytuacji i jest partykularna, gdyż organizowane są kursy i oferty ograniczone czasowo. Kościelne kształcenie ukierunkowane jest biograficznie i każdą historię życia traktuje poważnie. W tym sensie oferta jest w owej kairologicznej wrażliwości „punktualna" (Englert) ${ }^{23}$. Kształcenie ma charakter towarzyszący, wspierający, mniej nauczający czy instruujący, jest jednak nastawione na wizje i nadzieje dotyczące dobrego i prawego życia, wywodzące się z tradycji judeochrześcijańskiej. Jest ono w związku z tym zdolne jednocześnie do prawdy i pluralizmu, gdyż szanuje obcość innego, a poprzez to uwydatnia bezwzględną prawdę Boga. Podkreślając jednak wizje i nadzieje w konkretnym kontekście i chcąc poświadczyć prawdę Boga przez ludzkie czyny, wyraża się ono jednocześnie krytycznie i konstruktywnie. W tym specyficznym sensie kształcenie dorosłych

23 Por. R. Englert, Glaubensgeschichte und Bildungsprozes. Versuch einer religionspädagogischen Kairologie, München 1985; R. Englert, S. Leimgruber Glaubensgeschichte und Bildungsprozess. Versuch einer religionspädagogischen Kairologie 2005. 
ukierunkowane jest na kształcenie podmiotowości, a więc służebnie. Nie służy ono jednak, choć zakorzenione jest kościelnie, Kościołowi, lecz samym podmiotom. Jednak jest ono w tym kościelnym zakorzenieniu służbą Kościoła człowiekowi żyjącemu w społeczeństwie. Na tym polega jego krytyczno-wyzwalający rys profetyczny.

W religijnym kształceniu dorosłych musi chodzić o to,

aby wspierać autorefleksję dorosłych i sterowanie własną biografią, rozwijać ich dojrzałość religijną oraz wzmacniać ich obywatelską odpowiedzialność. Religijne kształcenie dorosłych chce jako źródło włączyć w te procesy kształcenia tradycję wiary judeochrześcijańskiej. Ostatecznie jednak uczestnicy muszą skonstruować własny obraz świata, znaleźć własną wiarę i rozwinąć własną tożsamośćc ${ }^{24}$.

I właśnie w ten sposób włączane są w to aspekty drażniące, dekonstruujące i wyzwalające. Religijne kształcenie dorosłych daje zatem nie tylko orientację w czasie braku orientacji. Proponuje ono

24 S. Leimgruber, R. Englert, Erwachsenenbildung stellt sich religiöser Pluralität. Zusammenfassende Thesen, [w:] R. Englert, S. Leimgruber, Erwachsenenbildung stellt sich religiöser Pluralität, dz. cyt., s. 288. 
perspektywę, która wykracza poza to, co dane z nadziei bożej, i obnaża różne logiki, które uważają się za jedyne słuszne ${ }^{25}$.

\section{3. \\ Kształcenie dorosłych a kształcenie osób starszych}

Starzy to dorośli. Dlatego wymienione zasady kościelnego kształcenia dorosłych dotyczą również ich. Ale są oni dorosłymi w specyficzny sposób, dlatego zasady kształcenia dorosłych należy dostosować do trzeciej fazy życia.

Dotychczas wypracowanie modelu kościelnego kształcenia ludzi starszych stanowi tylko dezyderat, co ma zapewne również związek z brakiem aktualnej refleksji naukowej nad tym problemem ${ }^{26}$. Jednakże po rozważaniach na temat diakonicznego, podmiotowego i biograficznego charakteru kształcenia dorosłych wydaje się oczywiste, że wymienione zadania związane z trzecią fazą życia powinny się stać przedmiotem teorii pedagogiczno-religijnych. Kształcenie

25 Por. R. Bergold, R. Boschki, Einführung in die religiöse Erwachsenenbildung, dz. cyt., s. 108-118.

26 Por. R. Bergold, R. Boschki, Einführung in die religiöse Erwachsenenbildung, dz. cyt.; zob. jednak Ch. Mulia, Kirchliche Altenbildung, dz. cyt. 
towarzyszące człowiekowi przez całe życie musi wspierać go i prowadzić zgodnie z wyzwaniami i możliwościami poszczególnych faz życia i konkretnych sytuacji. Pedagog religijny Bernd Schröder rozróżnia tu dwie formy kształcenia:

a. Kształcenie jako przygotowanie do obcowania ze starością. Chodzi w nim o gotowość do podjęcia międzypokoleniowej nauki ze starszymi osobami trzeciej i czwartej fazy, podejmowanie prac społecznych na rzecz wspierania osób starszych na co dzień, w opiece, w hospicjum, także po to, aby się świadomie zmierzyć z własnym starzeniem się i umieraniem w starzejącym się społeczeństwie. Ważną rolę odgrywają tu obrazy i wzorce oraz wyobrażenia ludzkiego umierania zaczerpnięte z religii judeochrześcijańskiej.

b. Kształcenie ludzi starszych. Tu natomiast chodzi o skonfrontowanie się z własnym starzeniem się, z kurczącymi się możliwościami i rosnącymi słabościami i ograniczeniami. Chodzi o rozwinięcie odpowiedzialności za samego siebie oraz innych wobec przemijania, ale też o rozwinięcie aktywności i kompetencji. Chodzi o zajęcie się umieraniem i śmiercią, własną i innych ${ }^{27}$.

Tego rodzaju kształcenie żywi się zmianą perspektywy. Tradycyjny, mocno ukierunkowany na wszel-

27 Por. B. Schröder, Religionspädagogik, dz. cyt., s. 506-507. 
kiego rodzaju deficyty obraz starości jako stadium naznaczonego wyniszczeniem i chorobą ustępuje miejsca obrazowi mocniej ukierunkowanemu na zasoby. W centrum takiego obrazu znajdują się szanse, przestrzenie dla swobodnego działania, wymagania wynikające z rosnącej międzypokoleniowej i społecznej odpowiedzialności, bez idealizującego jednak banalizowania ograniczeń tej fazy życia ${ }^{28}$.

Jeśli kształcenie dorosłych ma być skonstruowane jako „szkoła języka wolności”, oznacza to dla kształcenia osób starszych zmianę perspektywy, która zmieni też sposób ich traktowania. Oznacza to dla samego kształcenia starszych, że w jego centrum znajdzie się samodzielność i wolność kształconych. Kształcenie myśli i jej wymagań, czy jest to Kościół, czy inne organizacje, lecz jest ukierunkowane na służbę ludziom starszym. Z obiektów opieki, jak przez całe lata byli przedstawiani przez gerontologię, z adresata dobrodusznych ofert Kościoła osoby starsze zostają podniesione do rangi podmiotu własnego kształcenia się w ramach własnych możliwości i zdolności ${ }^{29}$.

28 Por. M. Habersetzer, Katechese in der dritten und vierten Altersphase, [w:] Handbuch der Katechese, Hg. A. Kaupp u. a., Freiburg i. Br. 2011, s. 489-506; tu: 490n.

29 Por. M. Blasberg-Kuhnke, Gerontologie und praktische Theologie..., dz. cyt., s. 327-370; U. Pohl-Patalong, Erwachsenenalter, [w:] Arbeitsbuch Religionspädagogik. Ein Begleitbuch für 
Tam jednak, gdzie kształtowanie się podmiotu, orientacja w otoczeniu i we własnej egzystencji, pedagogiczne przetwarzanie własnych doświadczeń, konkretne oferty nie ujmują człowieka w całości, tam istnieje zagrożenie, że kształcenie ludzi starszych stanie się nieludzkie ${ }^{30}$.

Te ogólne zasady kształcenia ludzi starszych nabierają jednak większego znaczenia na tle ich specyficznej religijności. Socjologia religii i teologia pastoralna obaliły stary przesąd, że „czego Jaś się nie nauczył, tego Jan nie będzie umiał". Istnieją rożne ślady religii i wiary w życiorysie człowieka, jak właśnie zobaczyliśmy $\mathrm{w}$ odniesieniu do religijności dorosłych ${ }^{31}$. Wprawdzie stopień socjalizacji religijnej w przypadku osób starszych jest prawdopodobnie znacznie większy, ale również tu widać efekty pluralizmu i indywidualizacji. Nie ma „pozytywnej zależności pomiędzy starzeniem się a religijnością. [...] raczej względna stałość religijności w życiorysie człowieka“. Konsekwencje dla pedagogiki religii są tu jasne: należy mianowicie

Studium und Praxis, Hg. G. Lämmermann, Gütersloh 2005, s. 245-284; tu: 278n.

30 R. Evers, Alphabetisierung in einer Sprache der Hoffnung. Erwägungen zur Altenbildung, [w:] Religiöse Bildung im Plural. Konzeptionen und Perspektiven, Hg. U. Pohl-Patalong, Hamburg 2003, s. 203-219; tu: 212.

31 Por. Ch. Mulia, Kirchliche Altenbildung..., dz. cyt., s. 116-129. 
liczyć się z przyrostem pokoleń zdystansowanych wobec religii, z pokoleniami poszukującymi religijności i ludźmi „niemuzykalnymi religijnie”, „dla których religijności wieku podeszłego trzeba będzie dopiero stworzyć odpowiednie formy towarzyszenia na drodze pastoralnej i religijno-pedagogicznej" ${ }^{32}$. Ważne jest to o tyle, że zwłaszcza modele wypracowane przez psychologię rozwojową wskazują na niezbywalne znaczenie religijności w okresie starości dla pracy nad tożsamością, trwającą przez całe życie ${ }^{33}$. Religijność jest nie tylko źródłem zdrowia i sensu, nawet jeśli się ją błędnie rozumie i jeśli traktuje się ją instrumentalnie. Negatywne obrazy Boga i nieprzyjemne doświadczenia wyniesione ze wspólnoty mogą jednak sprawić, że to źródło przestanie bić. Z badań empirycznych wynika, że religia, nadzieja na zbawiającego Boga oraz włączenie we wspólnotę mogą pomóc poradzić sobie z ludzkim zadaniem rozwoju, gdyż można znaleźć sens i siłę zbawczą nawet we fragmentarycznym i ułomnym obrazie Boga.

W świetle wiary ostatnie lata wcale nie są końcem życia, lecz zawierają się w "już teraz" i ,jeszcze nie” obiecanego życia wiecznego. Taka wiara zmienia pa-

\footnotetext{
32 M. Blasberg-Kuhnke, Religiosität im Alter, NHbrpGb 2002, s. 211.

33 Por. tamże.
} 
trzenie na starość i ludzi starych. W ten sposób starość - w przeciwieństwie do ducha czasu i zapewne zaskakująco też dla samych chrześcijan - staje się znakiem nadziei" ${ }^{34}$.

Kościelne kształcenie osób starszych znajduje zatem swój najwyższy sens w wyczuwaniu ich egzystencjalnych potrzeb, we wspieraniu poszukiwań i zainicjowanych przez nich samych procesów uczenia się oraz w pobudzaniu do krytycznej konfrontacji z własnymi biograficznymi doświadczeniami w Kościele i społeczeństwie ${ }^{35}$. Martina Blasberg-Kuhnke zawęża to zorientowane na osoby starsze pojęcie kształcenia do „kształcenia kryzysowego”, które ma być pomocne zwłaszcza w trudnych sytuacjach życiowych. Odróżnia ona kryzysy przewidywalne, takie jak przejście na emeryturę lub wyprowadzenie się dzieci, od doraźnych kryzysów życiowych, takich jak choroba czy owdowienie. W pierwszym przypadku kształcenie miałoby charakter prewencyjny, w drugim zaś interwencyjno-wspierający, w którym sytuacyjnie i egzystencjalnie podkreślana byłaby nadzieja judeochrześcijańska ${ }^{36}$.

34 U. Feeser-Lichterfeld, cyt. za: Habersetzer, Katechese in der dritten und vierten Altersphase, dz. cyt., s. 492.

35 Por. Ch. Mulia, Kirchliche Altenbildung..., dz. cyt., s. 338.

36 Por. M. Blasberg-Kuhnke, Bildung in den Krisen des Alters - antizipatorisch und aktuell, [w:] A. Wittrahm, M. Blas- 
Można by tutaj wymienić różne obszary treści i sensu, w których odbywałoby się takie kształcenie ludzi starszych ${ }^{37}$. Skoncentruję się na trzech $\mathrm{z}$ nich:

\section{1.}

Narracja biograficzna jako

zrozumienie samego siebie

Nawiązując do rozwijanej przez Eriksona pracy nad tożsamością należy opowiedzieć własne życie w świetle wiary. Narracje biograficzne są tu ważnym procesem samozrozumienia. Wysłuchanie opowieści ludzi starszych, potraktowanie ich z należytą powagą, pomaganie $\mathrm{w}$ skonstruowaniu opowieści o własnym życiu, zaakceptowanie ich i czerpanie z nich siły na przyszłość to istotna treść kształcenia ludzi starszych. Specjalne kawiarenki mogą stać się miejscem takiej pracy nad własną biografią.

berg-Kuhnke, Altern in Freiheit und Würde. Handbuch christliche Altenarbeit, München 2007, s. 270-276; tu: 273-274.

$37 \mathrm{Na}$ ten temat U. Pohl-Patalong, Erwachsenenalter, dz. cyt., s. 281-283; por. F. Schweitzer, Postmoderner Lebenszyklus und Religion..., dz. cyt., s. 154n.; Ch. Mulia (Kirchliche Altenbildung: Herausforderungen - Perspektiven - Konsequenzen, dz. cyt., s. 129-332) wymienia cztery pola sensu wraz z przykładami praktycznych projektów: 1 . biografia; 2 . produktywność, dobrowolne zaangażowanie oraz społeczeństwo cywilne; 3 . kultura, sztuka, estetyka; 4. ciało, zdrowie, podróże, duchowość. 
3.2.

Rozwijanie kompetencji

Chodzi tu o konkretne poszerzenie wiedzy, sprawności i umiejętności, które widziane są jednak ciągle w świetle własnej egzystencji i własnej religii ludzi starszych. Ćwiczenia w uczeniu się i trening pamięciowy, wycieczki tematyczne, zaangażowanie społeczne w działalność parafialnych placówek Caritas, na rzecz społeczności w swoim miejscu zamieszkania czy w dziełach Kolpinga to odpowiednie propozycje.

3.3.

Odniesienie do Kościoła i społeczeństwa

Jeśli kształcenie osób starszych ma na celu uzdolnienie ich do bycia podmiotami, to wspólnoty muszą stworzyć im przestrzeń do samorozwoju, w której sami będą mogli coś zdziałać. Ale musi to także zadziałać odwrotnie, a mianowicie wspólnoty same muszą się otworzyć i zmienić. Bo one również muszą przyjąć to, co ludzie starsi mają im do powiedzenia. Pojedyncze narracje ludzi starszych mogą się okazać istotne dla wielkiej narracji Kościoła. Osoby starsze są nie tylko adresatami. Międzypokoleniowy dialog w samym Kościele i w społeczeństwie może czerpać z tego, że także młodzi uczą się od starszych i w obrębie Kościoła - mogą wzrastać w wierze. Pod 
tym warunkiem wspólnota Kościoła mogłaby się stać „podtrzymującym otoczeniem” (J. W. Fowler) ${ }^{38}$, które wspiera tożsamość i jest dla niej domem.

\section{4. \\ Perspektywy i dezyderaty}

Niniejsze rozważania miały pokazać, jak wielkie znaczenie kształcenie osób starszych ma dla tworzenia ich tożsamości, dla ich religijnego samospełnienia oraz dla społeczeństwa. Tym istotniejszy jest fakt, że dotychczas istnieją $\mathrm{w}$ tym względzie tylko propozycje praktyczno-teologiczne. A przecież konieczne jest odpowiednie rozszerzenie kształcenia ludzi starszych na trzecią i czwartą fazę życia właśnie z perspektywy religijno-pedagogicznej. Pojawiają się przy tym jednak trzy dodatkowe problemy, którymi trzeba zająć się pilnie:

a. zdolność do pluralizmu: jak osoby zajmujące się kształceniem religijnym ludzi starszych pojmują kształcenie w warunkach postępującego pluralizmu i sekularyzacji? Dotychczas kształcenie osób starszych zakładało, że osoby starsze są w znacznym stopniu lub zupełnie zsocjalizowane religijnie. Jakich strategii po-

38 M. Blasberg-Kuhnke, Bildung in den Krisen des Alters - antizipatorisch und aktuell, dz. cyt., s. 274. 
trzeba obecnie, kiedy wieku sędziwego dożywają ludzie w znacznym stopniu „religijnie niemuzykalni”?

Do jakich koncepcji i dydaktyk pedagogiczno-religijnych sięgnąć, aby „otworzyć horyzont kościelnego kształcenia ludzi starszych, wrażliwego na środowisko i wieloperspektywicznego"? ${ }^{39}$ Prawdopodobnie pomocna okazałaby się ścisła współpraca ze szkolnym nauczaniem religii, które o wiele intensywniej walczy już o zdolność bycia pluralistycznym i heterogenicznym;

b. sprawiedliwość: pedagogika religii bardzo wolno zdaje sobie sprawę ze swego deficytu postrzegania i refleksji nad ogromem zjawisk związanych ze sprawiedliwością kształcenia ${ }^{40}$. W kościelnym kształceniu ludzi starszych zdaje się to wyglądać podobnie. Koncepcyjne projekty wypadają blado. Żeby być szczerym, to przy wszystkich podniosłych zapewnieniach faktyczny udział osób starszych i niewykształconych oraz społecznie pokrzywdzonych w religijno-kościelnym kształceniu dorosłych procentowo jest raczej marginalny. Efekt św. Mateusza, według którego ci, którzy mają, otrzymują jeszcze więcej, działa także tu. To wymaga od kościelnej pracy na rzecz

39 Ch. Mulia, Kirchliche Altenbildung: Herausforderungen - Perspektiven - Konsequenzen, dz. cyt., s. 340.

40 Por. ostatnio B. Grümme, Bildungsgerechtigkeit. Eine religionspädagogische Herausforderung, dz. cyt. 
ludzi starszych „przeniesienia akcentu ze znanych grup docelowych"41. Konkretne, różnorodne propozycje należy zorientować na podmiot i uczestnika w procesie dialogu i rozwinąć pod kątem potrzeb ludzi starszych, zapraszając ich do dialogu;

c. znalezienie własnego profilu: na czym polega specyfika religijnego kształcenia ludzi starszych $\mathrm{w}$ pluralizmie $\mathrm{w}$ porównaniu $\mathrm{z}$ ogólnym kształceniem starszych? Przedmiot, metody, treści i dydaktyki są tak samo podobne jak kontekstualne wyzwania. Można by uwypuklić specyfikę na wspomnianym już polu uczenia się przez całe życie, które w warunkach społecznych procesów nowoczesności i związanych $\mathrm{z}$ nimi zjawisk przyspieszenia jest konieczne. Jednocześnie jednak wiąże się z tym zagrożenie bycia nieustannie pod presją ciągłej gotowości do uczenia się. Kształcenie ludzi dorosłych jest w związku z tym ciągle konfrontowane z narastającym zjawiskiem zinternalizowanej i zindywidualizowanej presji wykorzystywania samego siebie, presji konsumpcji oraz estetycznej autostylizacji ${ }^{2}$. To, co kiedyś było postępem społecznym ikulturowym, zostaje przeniesione najednostkę. Socjologia określa to mianem „autoreferencyjnej

\footnotetext{
${ }^{41}$ Könemann 2013, 190. Por. 189nn.

42 Por. A. Honneth, Das Ich im Wir. Studien zur Anerkennungstheorie, Berlin 2010, s. 202-222; A. Reckwitz, Die Erfindung der Kreativität. Zum Prozess gesellschaftlicher Ästhetisierung, Berlin 2012, s. 198-239.
} 
maksymalizacji”"43. I właśnie do tego apeluje wspomniana na wstępie strategia przemysłu reklamowego. Kościelne kształcenie ludzi starszych, które czerpie ze źródeł antropologii judeochrześcijańskiej i przyjmuje w związku z tym obraz człowieka obdarowanego bez żadnych zasług i bezwarunkowo akceptowanego, mogłoby działać w dwojaki sposób: w perspektywie wewnętrznej umożliwiałoby krytyczną konfrontację z rzekomo skrojoną na ich miarę reklamą i „stwarzać alternatywy dla konsumpcji w podeszłym wie$\mathrm{ku}^{\prime \prime 4}$. W perspektywie zewnętrznej zaś zniekształcałoby krytycznie społeczny ideał ,ja jako jedynego źródła”45. Dokładnie na tym polegałaby specyfika kościelnego kształcenia dorosłych w porównaniu z ogólną geragogiką oraz jednocześnie jej publiczny charakter $^{46}$. Zamiast koncentrować się tylko na sobie, angażuje się ono się na zewnątrz, w zmienione współżycie wszystkich ludzi - „w pracy dla całego społeczeństwa i przyszłych pokoleń". Albowiem poszukiwanie

43 S. Gärtner, Selbstreferentielle Maximierung, [w:] Praktische Theologie in der Spätmoderne. Herausforderungen und Entdeckungen, Hg. S. Gärtner u. a., Würzburg 2014, s. 113.

44 F. Schweitzer, Postmoderner Lebenszyklus und Religion..., dz. cyt., s. 155.

45 A. Reckwitz, Die Erfindung der Kreativität..., dz. cyt., s. 198.

46 W tym pokazała się także - przy całym podobieństwie - jego specyfika wobec krytycznego pojęcia kształcenia dorosłych: por. Ch. Zeuner, Erwachsenenbildung: Entwicklung einer kritischen Theoriediskussion, Bonn 2011, s. 53-64. 
„osobistego spełnienia w podejmowaniu nowych zadań i odkrywaniu nowych perspektyw można owocnie połączyć z przeżywaną po chrześcijańsku odpowiedzialnością"47. Kościelnemu kształceniu osób starszych należałoby w związku z tym nadać profil elementu publicznej pedagogiki religii. A z szydełkowaniem i grą w bingo miałoby to niewiele wspólnego.

tłum. ks. Jan Dziedzic, Robert Samek

\section{Summary}

Not only crocheting and bingo games. The age when religious education challenge

Religious education takes place mainly in school or in parishes. There it has to deal with children, adolescents and adults. However, with the demographic change ancients are increasingly getting into the focus of religious education. The following text outlines the profile and basics of this kind of religious education for ancient.

Keywords: elderly people, pastoral care, Church and the aging

47 F. Schweitzer, Postmoderner Lebenszyklus und Religion, dz. cyt., S. 156. 


\section{Bibliografia}

Becker K., Konzeptionen der Erwachsenenkatechese; [w:] Handbuch der Katechese, Hg. A. Kaupp u. a., Freiburg i. Br. 2011, s. $432-445$.

Berger P. L., Der Zwang zur Häresie. Religion in der pluralistischen Gesellschaft, Freiburg i. Br. 2000.

Bergold R., Boschki R., Einführung in die religiöse Erwachsenenbildung, Darmstadt 2014.

Blasberg-Kuhnke M., Gerontologie und praktische Theologie. Studien zu einer Neuorientierung der Altenpastoral, Düsseldorf 1985.

Blasberg-Kuhnke M., Bildung in den Krisen des Alters - antizipatorisch und aktuell, [w:] A. Wittrahm, M. Blasberg-Kuhnke, Altern in Freiheit und Würde. Handbuch christliche Altenarbeit, München 2007, s. 270-276.

Englert R., Glaubensgeschichte und Bildungsprozess. Versuch einer religionspädagogischen Kairologie, München 1985.

Englert R., Religiöse Erwachsenenbildung. Situation - Probleme - Handlungsorientierung, Stuttgart 1992.

Erwachsenenbildung stellt sich religiöser Pluralität, Hg. R. Englert, S. Leimgruber, Freiburg i. Br. 2005.

Evers R., Alphatbetisierung in einer Sprache der Hoffnung. Erwägungen zur Altenbildung, [w:] Religiöse Bildung im Plural. Konzeptionen und Perspektiven, Hg. U. Pohl-Patalong, Hamburg 2003, s. 203-219.

Fürst W., Gestalten erwachsener Religiosität, [w:] NHbrpGb 2002, s. 204-209. 
Gärtner S., Selbstreferentielle Maximierung, [w:] Praktische Theologie in der Spätmoderne. Herausforderungen und Entdeckungen, Hg. S. Gärtner u. a., Würzburg 2014, s. 113-118.

Grümme B., Religionsunterricht und Politik. Bestandsaufnahme - Grundsatzüberlegungen - Perspektiven für eine politische Dimension des RU, Stuttgart 2009.

Grümme B., Menschen bilden. Eine religionspädagogische Anthropologie, Freiburg i. Br. 2012.

Grümme B., Bildungsgerechtigkeit. Eine religionspädagogische Herausforderung, Stuttgart 2014.

Habersetzer M., Katechese in der dritten und vierten Altersphase, [w:] Handbuch der Katechese, Hg. A. Kaupp u. a., Freiburg i. Br. 2011, s. 489-506.

Knoblauch H., Populäre Religion. Auf dem Weg in eine spirituelle Gesellschaft, Frankfurt a. M. 2009.

Honneth A., Das Ich im Wir. Studien zur Anerkennungstheorie, Berlin 2010.

Könemann J., Kontexte und Bedingungen religiös-theologischer Erwachsenenbildung, „Forum Erwachsenenbildung. Beiträge und Berichte" Heft 3 (2010), s. 4-9.

Könemann J., Konsequenzen aus den pastoralen Entwicklungen für die Erwachsenenbildung, „Erwachsenenbildung” 57 (2010), s. 146-150.

Könemann J., Lebenslanges Lernen: Lernen für alle - immer? Bedeutung und Wirkung eines Topos, „Diakonia” 44 (2013), s. 184-191.

Konstrukte gelingenden Alterns, Hg. M. Kumlehn, A. Kubik, Stuttgart 2012. 
Leimgruber S., Englert R., Erwachsenenbildung stellt sich religiöser Pluralität. Zusammenfassende Thesen, [w:] Erwachsenenbildung stellt sich religiöser Pluralität, Hg. R. Englert, S. Leimgruber, Freiburg i. Br. 2005, 297-291.

Mulia Ch., Kirchliche Altenbildung: Herausforderungen - Perspektiven - Konsequenzen, Stuttgart 2011.

Pohl-Patalong U., Erwachsenenalter, [w:] Arbeitsbuch Religionspädagogik. Ein Begleitbuch für Studium und Praxis, Hg. G. Lämmermann u. a., Gütersloh 2005, s. 245-284.

Reckwitz A., Die Erfindung der Kreativität. Zum Prozess gesellschaftlicher Ästhetisierung, Berlin 2012.

Rosa H., Beschleunigung. Die Veränderung der Zeitstrukturen in der Moderne, Frankfurt a. M. 2005.

Schröder B., Religionspädagogik, Tübingen 2012.

Schweitzer F., Religionspädagogik, Gütersloh 2006.

Taylor Ch., Ein Säkulares Zeitalter, Frankfurt a. M. 2009.

Wittrahm A., Alter als Entwicklungsaufgabe, [w:] A. Wittrahm, M. Blasberg-Kuhnke, Altern in Freiheit und Würde. Handbuch christliche Altenarbeit, München 2007, s. 85-93.

Ziebertz H.-G., Wozu religiöses Lernen? Religionsunterricht als Hilfe zur Identitätsbildung, [w:] G. Hilger u. a., Religionsdidaktik, München 2010, s. 142-155.

Bernhard Grümme, Nie tylko szydełkowanie i gra w bingo. Starość jako wyzwanie religijno-pedagogiczne, [w:] Starość. Problem czy szansa? Refleksja pastoralnoteologiczna, red. Jan Dziedzic, Kraków 2015, s. 209-241.

http://dx.doi.org/10.15633/9788374384278.08 